\title{
Heavy metal contamination of paddy soils and rice (Oryza sativa L.) from Kočani Field (Macedonia)
}

\author{
Nastja Rogan · Todor Serafimovski - Matej Dolenec • \\ Goran Tasev · Tadej Dolenec
}

Received: 14 January 2008/ Accepted: 7 July 2008

(C) Springer Science+Business Media B.V. 2008

\begin{abstract}
This research focuses on the heavy metal contamination of the paddy soils and rice from Kočani Field (eastern Macedonia) resulting from irrigation by riverine water impacted by past and present base-metal mining activities and acid mine drainage. Very high concentrations of $\mathrm{As}, \mathrm{Cd}, \mathrm{Cu}, \mathrm{Pb}$ and $\mathrm{Zn}$ were found in the paddy soils (47.6, 6.4, 99, 983 and $\left.1,245 \mu \mathrm{g} \mathrm{g}^{-1}\right)$ and the rice $(0.53,0.31,5.8$, 0.5 and $67 \mu \mathrm{g} \mathrm{g}^{-1}$ ) in the western part of Kočani Field, close to the Zletovska River, which drains the mining facilities of the $\mathrm{Pb}-\mathrm{Zn}$ mine in Zletovo. In terms of health risk, the observed highest concentrations of these elements in the rice could have an effect on human health and should be the subject of further investigations.
\end{abstract}

Keywords Heavy metals · Paddy soil · Rice (Oryza sativa L.) · Contamination . Mining activities $\cdot$ Kočani Field $\cdot$ Macedonia

N. Rogan - M. Dolenec $\cdot$ T. Dolenec $(\square)$

Department of Geology, Faculty of Natural Sciences and Engineering, University of Ljubljana,

Aškerčeva 12, 1000 Ljubljana, Slovenia

e-mail: tadej.dolenec@ntf.uni-lj.si

T. Serafimovski · G. Tasev

Faculty of Mining and Geology, Goce Delčev 89,

Stip, Macedonia

T. Dolenec

Jožef Stefan Institute, Jamova 39, 1000 Ljubljana, Slovenia

\section{Introduction}

Base-metal mining together with milling and grinding operations, concentrating ore and the disposal of tailings along with the acid mine and mill wastewater are some of the most important sources of heavy metals in the environment (Adriano 1986). Therefore, elevated concentrations of heavy metals can be found in and around abandoned and active mines due to the discharge and dispersion of mine waste materials, including tailings and acid mine drainage effluents into nearby agricultural soils, food crops, riverine water and stream sediments (Jung 2001; Korre et al. 2002; Lee et al. 2001; Liu et al. 2005; Lu and Zhang 2005; Simmons et al. 2005; Witte et al. 2004; Wong et al. 2002; Yang et al. 2004). It is well known that heavy metals in agricultural soils can influence both crop yield and quality, and soil containing various elements is a primary nutrient medium for plants. Food crops grown in contaminated areas may accumulate much higher than normal amounts of heavy metals, which may pose a significant public health risk to the local community.

Although numerous studies have been undertaken to investigate the heavy metal concentrations in soil and edible plants derived from the mining activities around the world, in Macedonia, such studies are very scarce (Dolenec et al. 2007). As a result, very little is known about the distribution and concentrations of heavy metals in the soil and food crops from different parts of Macedonia, which could be affected due to 
historical and/or recent base-metal mining and milling operations as well as from irrigation with acid mine drainage and other mining effluents that have an impact on riverine water.

Such an example is Kočani Field in eastern Macedonia, where the base-metal mining history of the region is very long and paddy rice (Oryza sativa L.) is one of the main agricultural products of the region. Previous investigations have shown that the riverine water from the more polluted Zletovska River and the less polluted Bregalnica River, used for irrigation of the Kočani paddy fields, were contaminated with heavy metals as a result of mining activities and acid mine drainage from the ZletovoKratovo and Sasa-Toranica ore districts (Serafimovski et al. 2005). Therefore, it is very likely that the paddy soil and rice grown in this area display raised levels of heavy metals. Repeated water sampling of the Zletovska River has suggested marked chemical variations of As (1.7-25 $\left.\mu \mathrm{g}^{-1}\right), \mathrm{Cd}\left(0.5-5 \mu \mathrm{g} \mathrm{l}^{-1}\right)$, $\mathrm{Cu}\left(6-10 \mu \mathrm{g} \mathrm{l}^{-1}\right), \mathrm{Pb}\left(10-24 \mu \mathrm{g} \mathrm{l}^{-1}\right)$ and $\mathrm{Zn}(101-$ $1,250 \mu \mathrm{g}^{-1}$ ), which can be explained by the waterflow conditions and the varying degrees of mine wastes from the $\mathrm{Pb}-\mathrm{Zn}$ Zletovo mine and the tailing dam leaching effluent inputs into the riverine water. The concentrations (in $\mu \mathrm{g} \mathrm{l}^{-1}$ ) of the aforementioned heavy metals in the less polluted Bregalnica River, also used for the irrigation of agricultural soils, are as follows: As (0.53), $\mathrm{Cd}$ (0.39), $\mathrm{Cu}$ (3), $\mathrm{Pb}$ (2.4) and $\mathrm{Zn}$ (67) (Serafimovski et al. 2005).

Therefore, the major aim of the present study was to compare the results with permissible levels of heavy metals ( $\mathrm{As}, \mathrm{Cd}, \mathrm{Cu}, \mathrm{Pb}$ and $\mathrm{Zn}$ ) in arable soils and crops and to reveal the influence of mining industry on the environment in Macedonia.

\section{Study area}

Kočani Field, well known for its paddy fields and thermal waters, is located in the eastern part of Macedonia, about $115 \mathrm{~km}$ from the capital city, Skopje. It is situated in the valley of the Bregalnica River, between the Osogovo Mountains in the north, and the Plačkovica Mountains in the south (Fig. 1). Its average length is $35 \mathrm{~km}$ and its width is about $5 \mathrm{~km}$. The paddy soil of Kočani Field was estimated to originate from the composite material of the sediment derived from igneous, metamorphic and sedimentary rocks transported by the Bregalnica River and its tributaries and deposited in the Kočani Depression (Dolenec et al. 2007).
Fig. 1 Map of the study area showing the drainage system of the Bregalnica River and its tributaries

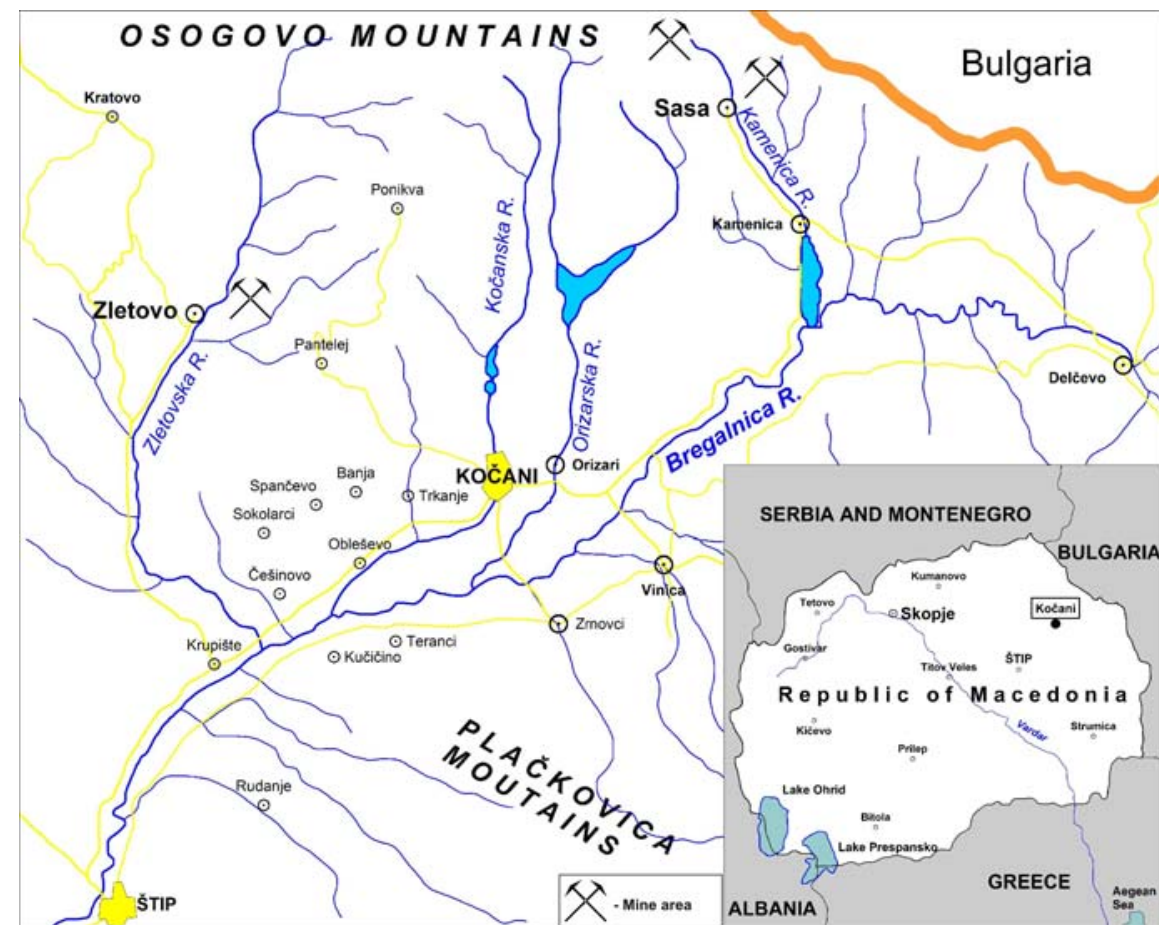


The broader region has a long history of mining dating to the pre-Middle Ages, with the most recent phase of mining starting after World War II. There are several $\mathrm{Pb}-\mathrm{Zn}$ ore deposits and $\mathrm{Ag}, \mathrm{As}, \mathrm{Cu}, \mathrm{Sb}, \mathrm{Ba}, \mathrm{Au}$ and $\mathrm{U}$ mineralization related to the Tertiary acidic to intermediate volcanogeno-intrusive complexes of the Besna Kobila-Osogovo Tassos metalogenic zone in the east and the Tertiary volcanogenic complexes of the Lece-Chalkidiki metalogenic zone in the north of Kočani Field (Serafimovski and Aleksandrov 1995).

The Zletovo lead-zinc deposit is situated along the active continental margin and is also intimately associated with the Tertiary volcanism and hydrothermal activity related with it. The Zletovo Mine is located in the eastern part of the Kratovo-Zletovo volcanic complex. From the geographical point of view the Zletovo Mine is located $5 \mathrm{~km} \mathrm{NW}$ of the village of Zletovo and about $7 \mathrm{~km}$ from the city of Probistip.

The first detailed exploration started in 1928 by the English Company Selection Mines Limited and was finished in 1939 when the Zletovo deposit was prepared for exploitation with an annual capacity of $120,000 \mathrm{t}$ raw ore. Nevertheless, continuous exploitation in the Zletovo Mine have started after World War II with an annual capacity of 400,000 t. Zletovo Mine is currently active with production of lead-zinc concentrate.

Mineral association comprises galena (the principal ore mineral) and sphalerite, with subordinate pyrite and lesser amounts of siderite, chalcopyrite, and occasional pyrrhotine, marcasite and magnetite. Minor occurrences of U-mineralisation have also been discovered (pitchblende).

The mining activities, the abandoned old mine sites and bare tailing, the large amounts of untreated waste material as well as the effluents from the $\mathrm{Pb}-\mathrm{Zn}$ ore deposits Zletovo and Sasa have induced widespread and high heavy metal loads across the entire region. The acid mine water and the effluents from the ore processing facilities and the tailings, which were discharged untreated into the Zletovska and Bregalnica Rivers used for the irrigation of paddy soil, represented a further pollution source that could seriously affect the soil as well as the food and feed crops of Kočani Field.

The Kočanska and Orizarska Rivers, two small tributaries of the Bregalnica River, were also used downstream for irrigation drainage of the $\mathrm{Pb}-\mathrm{Zn}$ mineralization of the southern part of the Osogovo Mountains, as well as the more or less untreated municipal wastes and domestic sewage of the cities of
Kočani and Orizari. Therefore, the surrounding paddy fields could also be affected by the continuing usage of this riverine water for irrigation all year around.

\section{Materials and methods}

Sampling of the soil and the rice was carried out in autumn 2005 in order to investigate the distribution and concentrations of potentially toxic heavy metals, including $\mathrm{As}, \mathrm{Cd}, \mathrm{Cu}, \mathrm{Pb}$ and $\mathrm{Zn}$, related to the basemetal mining activities of the region. The sampling locations of the study area are shown in Fig. 2.

Soil sampling and analysis

Soil was collected from 38 locations using seven profiles (sections I-VII) across the Kočani paddy fields (Fig. 2). Near-surface soils were collected, because in the agricultural soil it is not possible to distinguish the A, B and C horizons. Each soil sample was made up of a composite of five subsamples taken from within a $1 \times 1 \mathrm{~m}$ square. After air-drying at $25^{\circ} \mathrm{C}$ for a week, the soil samples were disaggregated, sieved to $2 \mathrm{~mm}$ and then ground in a mechanical agate grinder to a fine powder ( $<63$ microns) for subsequent geochemical analysis.

All the paddy-soil samples were analysed for their $\mathrm{As}, \mathrm{Cd}, \mathrm{Cu}, \mathrm{Pb}$ and $\mathrm{Zn}$ concentrations in a certified commercial Canadian laboratory (Acme Analytical Laboratories, Ltd.) after extraction for $1 \mathrm{~h}$ with 2-2-2$\mathrm{HCl}-\mathrm{HNO}_{3}-\mathrm{H}_{2} \mathrm{O}$ at $95^{\circ} \mathrm{C}$ by inductively coupled plasma mass spectrometry (ICP-MS). The accuracy and precision of the soil analyses were assessed by using international reference material such as Canadian certifite reference material project (CCRMRP) SO-1 (soil) and United States geological survey (USGS) G-1 (granite). The analytical precision and the accuracy were better than $\pm 5 \%$ for the analysed elements. This was indicated by the results of duplicate measurements on ten soil samples as well as duplicate measurements on the G-1 and SO-1 standards.

Rice sampling and analysis

Rice-grain samples with a hull were collected during harvest time at the beginning of November 2005. The hulled rice grains were sampled at 14 sampling sites at the same locations as the corresponding soil samples 
Fig. 2 Sampling location map of the study area: R I-VII soil samples unpolished rice samples

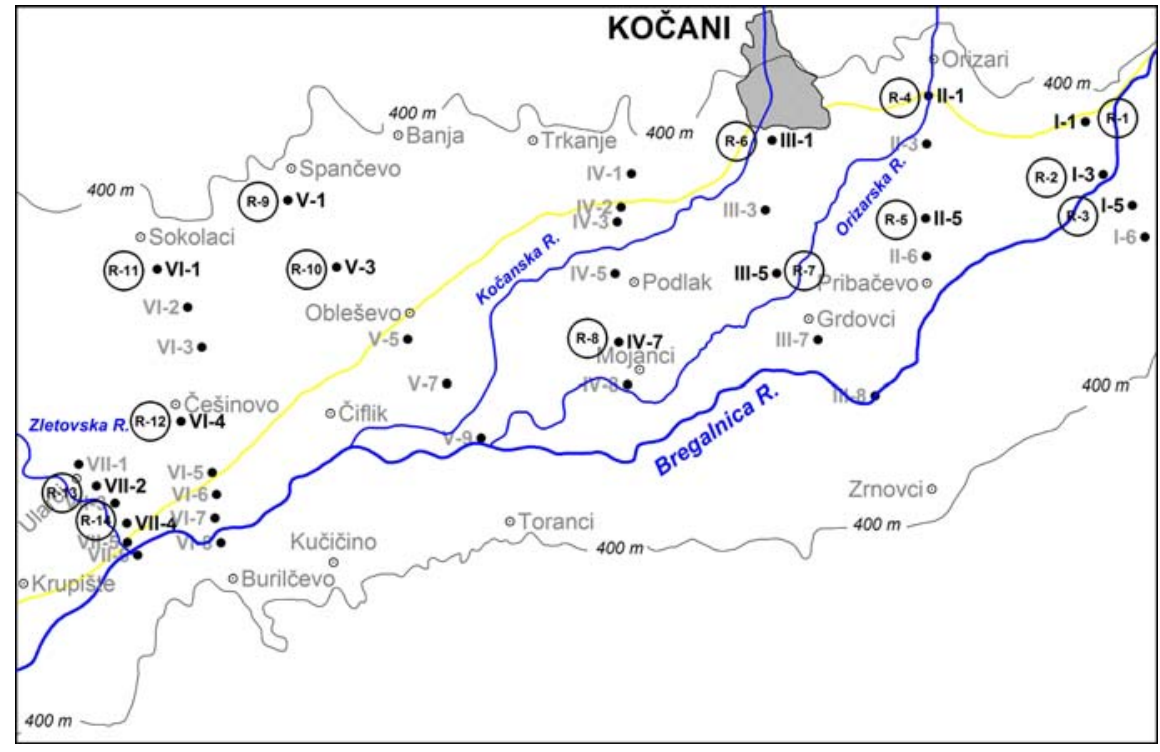

(Fig. 2). At each sampling site the rice grains were taken over an area of $10 \times 10 \mathrm{~m}$ to obtain a final composite sample of about $1 \mathrm{~kg}$. All the samples were collected and stored in polythene bags and brought to the laboratory for further preparation and treatment. In the laboratory the rice grains were washed three times with distilled water to eliminate soil particles and airborne pollutants, and were then oven-dried to constant weight at $75^{\circ} \mathrm{C}$ for $72 \mathrm{~h}$. Each oven-dried sample of rice with a husk was dehulled with a ceramic pestle and mortar. The dehulled rice was ground in an agate mortar until it could pass through a 63-micronmesh sieve. Powdered samples were then stored in clean dry glass containers before analysis.

The rice samples were measured for their As, Cd, $\mathrm{Pb}$ and $\mathrm{Zn}$ content after acid digestion in environmental-grade nitric acid and then analysed by IPCMS in the same laboratory (Acme Analytical Laboratories, Ltd.). Quality checks included the analysis of certified reference materials (rice flour SRM 1568 from the National Bureau of Standards-NBS), blanks and duplicate samples. Reproducibility was estimated to be better than $\pm 10 \%$.

\section{Results and discussion}

Heavy metal concentration in the soil

Concentrations of $\mathrm{As}, \mathrm{Cd}, \mathrm{Cu}, \mathrm{Pb}$ and $\mathrm{Zn}$ in the paddy soil from Kočani Field together with the assumed permissible level of heavy metals adopted by the National Environmental Protection Agency of Slovenia (Uradni list RS 1996) and their typical contents of comparable soils around the world (Bowen 1979) as well as the maximum allowable concentrations (MAC) of trace elements in agricultural soil proposed by the German Federal Ministry of Environment (1992) are presented in Table 1. Table 2 shows the main statistical parameters (mean, median, range and standard deviation [SD]) for the analysed paddy-soil samples.

The As concentration in uncontaminated, untreated soils rarely exceeded $10 \mu \mathrm{g} \mathrm{g}^{-1}$ (Adriano 1986). In the western Hunan mining area in China the As content in paddy soil polluted by mine tailing and mining/ smelting wastewater was in the range $325-4,317$ $\mu \mathrm{g} \mathrm{g}^{-1}$ (Yang et al. 2004). In agricultural soil impacted due to past mining activities around the Songcheon $\mathrm{Au}-\mathrm{Ag}$ mine in South Korea As concentrations were in the range 53-490 $\mu \mathrm{g} \mathrm{g}^{-1}$, with a mean value of $230 \mu \mathrm{g} \mathrm{g}^{-1}$ (Lee et al. 2005). In addition, Liu et al. (2005) found the mean concentration for As in agricultural soil from the Chenzhou $\mathrm{Pb}-\mathrm{Zn}$ mineaffected area (Hunan, China) to be $459 \mu \mathrm{g} \mathrm{g}^{-1}$. In this study, the median concentrations of As $\left(6.7 \mu \mathrm{g} \mathrm{g}^{-1}\right)$ in the paddy soil and the range of $3.1-47.6 \mu \mathrm{g} \mathrm{g}^{-1}$ (Table 2) were much lower than those previously reported As concentrations in soils affected by mining activities. However, the elevated concentrations of As in the range from 20.7 to $47.6 \mu \mathrm{g} \mathrm{g}^{-1}$ found in the 
Table 1 Total elemental concentrations in the paddy soil of Kočani Field: (1) typical contents of $\mathrm{As}, \mathrm{Cd}, \mathrm{Cu}, \mathrm{Pb}$ and $\mathrm{Zn}$ in comparable soils around the world (Bowen 1979); (2) limits for elemental concentrations in soil (Environmental Protection
Agency of Slovenia (Uradni list RS 1996); (3) maximum allowable concentrations (MAC) of trace elements in agricultural soils proposed by the German Federal Ministry of the Environment (1992)

\begin{tabular}{|c|c|c|c|c|c|c|}
\hline \multicolumn{2}{|l|}{ Element } & \multirow[t]{2}{*}{ As $\left(\mu \mathrm{g} \mathrm{g}^{-1}\right)$} & \multirow[t]{2}{*}{$\mathrm{Cd}\left(\mu \mathrm{g} \mathrm{g}^{-1}\right)$} & \multirow[t]{2}{*}{$\mathrm{Cu}\left(\mu \mathrm{g} \mathrm{g}^{-1}\right)$} & \multirow[t]{2}{*}{$\mathrm{Pb}\left(\mu \mathrm{g} \mathrm{g}^{-1}\right)$} & \multirow[t]{2}{*}{$\overline{\mathrm{Zn}\left(\mu \mathrm{g} \mathrm{g}^{-1}\right)}$} \\
\hline Location & Sample no. & & & & & \\
\hline $\mathrm{I}-1$ & 1 & 3.4 & 0.1 & 15 & 19 & 53 \\
\hline $\mathrm{I}-3$ & 2 & 18.7 & 0.5 & 40 & 81 & 162 \\
\hline $\mathrm{I}-5$ & 3 & 5.6 & 0.2 & 32 & 19 & 85 \\
\hline I-6 & 4 & 5.1 & 0.1 & 26 & 13 & 70 \\
\hline II-1 & 5 & 6.1 & 0.2 & 27 & 27 & 93 \\
\hline II-3 & 6 & 5.0 & 0.1 & 29 & 21 & 81 \\
\hline II-5 & 7 & 5.3 & 0.2 & 25 & 21 & 80 \\
\hline II-6 & 8 & 11.8 & 0.3 & 26 & 32 & 100 \\
\hline III-1 & 9 & 6.1 & 0.2 & 27 & 18 & 89 \\
\hline III-3 & 10 & 3.1 & 0.4 & 33 & 20 & 95 \\
\hline III-5 & 11 & 8.3 & 0.2 & 33 & 24 & 102 \\
\hline III-7 & 12 & 8.2 & 0.2 & 17 & 22 & 64 \\
\hline III-8 & 13 & 4.2 & 0.1 & 22 & 11 & 64 \\
\hline IV-1 & 14 & 3.8 & 0.1 & 29 & 14 & 74 \\
\hline IV-2 & 15 & 3.5 & 0.2 & 17 & 18 & 68 \\
\hline IV-3 & 16 & 4.3 & 0.3 & 23 & 19 & 102 \\
\hline IV -5 & 17 & 6.3 & 0.2 & 26 & 15 & 94 \\
\hline IV-7 & 18 & 8.1 & 0.2 & 26 & 17 & 83 \\
\hline IV-8 & 19 & 5.9 & 0.2 & 29 & 18 & 96 \\
\hline V-1 & 20 & 10.0 & 0.2 & 19 & 31 & 85 \\
\hline V-3 & 21 & 7.8 & 0.2 & 20 & 27 & 73 \\
\hline V-5 & 22 & 6.5 & 0.2 & 25 & 22 & 98 \\
\hline V-7 & 23 & 6.4 & 0.2 & 23 & 18 & 67 \\
\hline V-9 & 24 & 4.5 & 0.2 & 21 & 19 & 69 \\
\hline VI-1 & 25 & 5.0 & 0.2 & 21 & 24 & 71 \\
\hline VI-2 & 26 & 6.8 & 0.3 & 25 & 39 & 76 \\
\hline VI-3 & 27 & 10.1 & 0.3 & 34 & 35 & 86 \\
\hline VI-4 & 28 & 9.9 & 0.3 & 29 & 41 & 105 \\
\hline VI-5 & 29 & 10.5 & 0.3 & 25 & 40 & 94 \\
\hline VI-6 & 30 & 11.5 & 0.3 & 28 & 45 & 107 \\
\hline VI-7 & 31 & 7.7 & 0.1 & 19 & 20 & 66 \\
\hline VI-8 & 32 & 6.2 & 0.2 & 30 & 16 & 72 \\
\hline VII-1 & 33 & 22.2 & 2.7 & 49 & 412 & 531 \\
\hline VII-2 & 34 & 42.0 & 5.6 & 99 & 892 & 1,134 \\
\hline VII-3 & 35 & 35.1 & 4.5 & 89 & 727 & 893 \\
\hline VII-4 & 36 & 47.6 & 6.4 & 80 & 983 & 1,245 \\
\hline VII-5 & 37 & 39.6 & 5.0 & 68 & 745 & 928 \\
\hline VII-6 & 38 & 20.7 & 2.0 & 47 & 296 & 384 \\
\hline 1 & & 6. & 0.35 & 30 & 35 & 90 \\
\hline 2 & & 20 & 1 & 60 & 85 & 200 \\
\hline 3 & & - & 1.5 & 60 & 100 & 200 \\
\hline
\end{tabular}


Table 2 Basic descriptive statistics of the elemental content in the paddy soil of Kočani Field

\begin{tabular}{lllllr}
\hline Element & $\mathrm{As}\left(\mu \mathrm{g} \mathrm{g}^{-1}\right)$ & $\mathrm{Cd}\left(\mu \mathrm{g} \mathrm{g}^{-1}\right)$ & $\mathrm{Cu}\left(\mu \mathrm{g} \mathrm{g}^{-1}\right)$ & $\mathrm{Pb}\left(\mu \mathrm{g} \mathrm{g}^{-1}\right)$ & $\mathrm{Zn}\left(\mu \mathrm{g} \mathrm{g}^{-1}\right)$ \\
\hline Mean & 11.4 & 0.9 & 33 & 128 & 206 \\
Median & 6.7 & 0.2 & 26 & 22 & 88 \\
Minimum & 3.1 & 0.1 & 15 & 11 & 53 \\
Maximum & 47.6 & 6.4 & 99 & 983 & 1,245 \\
SD & 11.3 & 1.7 & 20 & 260 & 310 \\
\hline
\end{tabular}

paddy soils from section VII significantly exceeded the level of $6 \mu \mathrm{g} \mathrm{g}^{-1}$ reported by Bowen (1979), and also the limit value of $20 \mu \mathrm{g} \mathrm{g}^{-1}$ reported by the Environmental Protection Agency of Slovenia (Table 1).

The average content of $\mathrm{Cd}$ in soils was between 0.07 and $1.1 \mu \mathrm{g} \mathrm{g}^{-1}$ (Kabata-Pendias and Pendias 2001). In agricultural soil, the background $\mathrm{Cd}$ level is about $1 \mu \mathrm{g} \mathrm{g}^{-1}$ or less (Whitby et al. 1978). Similar background values of $0.35 \mu \mathrm{g} \mathrm{g}^{-1}$ were also reported for soils all around the world by Bowen (1979). According to Jung and Thornton (1996) the mean concentrations of $\mathrm{Cd}$ in soils in an area contaminated by past $\mathrm{Pb}-\mathrm{Zn}$ mining in northwest Korea were $11.8 \mu \mathrm{g} \mathrm{g}^{-1}$ (0-15 cm depth), $6.0 \mu \mathrm{g} \mathrm{g}^{-1}(15-30 \mathrm{~cm} \mathrm{depth)}$ and

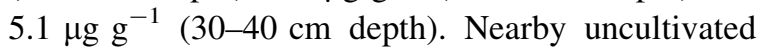
soils and household garden soils contained less than $3.3 \mu \mathrm{g} \mathrm{g}^{-1} \mathrm{Cd}$. Elevated concentrations of $\mathrm{Cd}$ ranging from 2.01 to $29.68 \mu \mathrm{g} \mathrm{g}^{-1}$ with a mean value of $13.59 \mu \mathrm{g} \mathrm{g}^{-1}$ were found in the paddy soil of the Lechang $\mathrm{Pb}-\mathrm{Zn}$ mine area in China irrigated with mining waste water (Yang et al. 2004). The mean Cd content in the agricultural soil of $6.77 \mu \mathrm{g} \mathrm{g}^{-1}$ was further reported from the Chenzho $\mathrm{Pb}-\mathrm{Zn}$ mineaffected area in Hunan, China (Liu et al. 2005). In the present study $\mathrm{Cd}$ concentrations in the paddy soil sampled were in the range $0.1-6.4 \mu \mathrm{g} \mathrm{g}^{-1}$, with a median value of $0.2 \mu \mathrm{g} \mathrm{g}^{-1}$ (Table 2), which was less than that of $0.35 \mu \mathrm{g} \mathrm{g}^{-1}$, reported for the worldaverage Cd content in soil by Bowen (1979). However, the highly elevated $\mathrm{Cd}$ concentration measured in the paddy soil in section VII, close to the Zletovska River, significantly exceeded the background $\mathrm{Cd}$ level of agricultural soil ( $1 \mu \mathrm{g} \mathrm{g}^{-1}$ or less) reported by Whitby et al. (1978) as well as the permitted value of 1 and $1.5 \mu \mathrm{g} \mathrm{g}^{-1}$, suggested by the environmental protection agencies of Slovenia and Germany (Table 1).

The total $\mathrm{Cu}$ content of world soil is $30 \mu \mathrm{g} \mathrm{g}^{-1}$, with values ranging from 2 to $250 \mu \mathrm{g} \mathrm{g}^{-1}$ (Bowen
1979). Contaminated soils around the $\mathrm{Pb}-\mathrm{Zn}$ Sambo mine in Korea vary between sampling sites, ranging up to $1,400 \mu \mathrm{g} \mathrm{g}^{-1}$ in soils near the mine site, although most soils did not exceed $100 \mu \mathrm{g} \mathrm{g}^{-1} \mathrm{Cu}$ due to the small extent of the $\mathrm{Cu}$ mineralization (Jung and Thornton 1996). The mean concentration of $\mathrm{Cu}$ in the agricultural soil around the Songcheon $\mathrm{Au}-\mathrm{Ag}$ mine (South Korea) was $120 \mathrm{\mu g} \mathrm{g}^{-1}$ (Lee et al. 2005), while in the agricultural soil affected by the $\mathrm{Pb}-\mathrm{Zn}$ mine, Chenzhou it was slightly higher, $174.03 \mu \mathrm{g} \mathrm{g}^{-1}$ (Liu et al. 2005). Cao and $\mathrm{Hu}$ (2000) also reported elevated concentrations of $\mathrm{Cu}\left(90.6 \pm 12.9 \mu \mathrm{g} \mathrm{g}^{-1}\right)$ in paddy soil irrigated with $\mathrm{Cu}$-rich wastewater. In this study, the $\mathrm{Cu}$ concentrations in the paddy soil samples were in the range $15-99 \mu \mathrm{g} \mathrm{g}^{-1}$ with a median value of $26 \mu \mathrm{g} \mathrm{g}^{-1}$ (Table 2), which was below the $\mathrm{Cu}$ content of world soil, i.e., $30 \mu \mathrm{g} \mathrm{g}^{-1}$ (Bowen 1979). The $\mathrm{Cu}$ concentration levels in the paddy soil samples in section VII were much higher, with a range of 47-99 $\mu \mathrm{g} \mathrm{g}^{-1}$, which exceeded the limit emission values of $60 \mu \mathrm{g} \mathrm{g}^{-1}$ reported by the environmental protection agencies of Slovenia and Germany (Table 1).

Agricultural soils have a wide range of $\mathrm{Pb}$ content, which depends on a number of factors, such as the parent material and the anthropogenic input (Adriano 1986). Jung and Thornton (1996) reported Pb concentrations in surface soils contaminated by the $\mathrm{Pb}-\mathrm{Zn}$ mine in Korea ranging from 41 to $29.900 \mu \mathrm{g} \mathrm{g}^{-1}$. In China, Yang et al. (2004) found Pb-contaminated paddy soil near the Lechang $\mathrm{Pb}-\mathrm{Zn}$ mine, with levels of $325-4,317 \mu \mathrm{g} \mathrm{g}^{-1}$ due to the irrigation with mining wastewater. The mean concentrations of $\mathrm{Pb}$ in the agricultural soil around the Songcheon $\mathrm{Au}-\mathrm{Ag}$ mine (South Korea) were reported to be $160 \mu \mathrm{g} \mathrm{g}^{-1}$ (Lee et al. 2005). A similar mean concentration level of $174 \mu_{\mathrm{g} \mathrm{g}^{-1}}$ was also measured in the Chenzhou $\mathrm{Pb}-\mathrm{Zn}$ mine (Hunan, China), which affected the agricultural soil (Liu et al. 2005). A median value of $22 \mu \mathrm{g} \mathrm{g}^{-1}$ for 
$\mathrm{Pb}$ and a range of 11-983 $\mu \mathrm{g} \mathrm{g}^{-1}$ (Table 2) were found during this study for the Kočani paddy soil. The highest concentration values were, however, measured in samples from the polluted section VII. Paddy soil from this section exhibited $\mathrm{Pb}$ concentrations in the range of 296-983 $\mu \mathrm{g} \mathrm{g}^{-1}$ (Table 1), which is above the median values of $\mathrm{Pb}$ content in contaminated agricultural soil reported by Lee et al. (2005) and Liu et al. (2005) as well as above the limits provided by the environmental protection agencies of Slovenia and Germany (Table 1).

Average $\mathrm{Zn}$ concentrations of $90 \mu \mathrm{g} \mathrm{g}^{-1}$ have been given for world soil by Bowen (1979). More recently, Berrow and Reaves (1984) reported a mean content of $40 \mu \mathrm{g} \mathrm{g}^{-1}$ for world soil. However, soil highly influenced by base-metal mining in Korea had $\mathrm{Zn}$ concentrations close to the mine of between 329 and $25.8 \mu \mathrm{g} \mathrm{g}^{-1}$, with an arithmetic mean of 8,300 $\mu \mathrm{g} \mathrm{g}^{-1}$. The $\mathrm{Zn}$ contents in other sites were, however, much lower $\left(<230 \mu \mathrm{g} \mathrm{g}^{-1}\right)$ (Jung and Thornton 1996). The mean concentrations of $\mathrm{Zn}$ in paddy soils impacted by past and/or recent mining activities were, according to Lee et al. (2001), in the range from 60 to $1,064 \mu \mathrm{g} \mathrm{g}{ }^{-1}$, with a mean value of $328 \mu \mathrm{g} \mathrm{g}^{-1}$, while those reported by Liu et al. (2005) ranged from 613 to $1,064 \mu \mathrm{g} \mathrm{g}^{-1}$, with a mean value of $855 \mu \mathrm{g} \mathrm{g}^{-1}$. Highly elevated concentrations of $\mathrm{Zn}$ were also found in the paddy soil from section VII, ranging from 384 to $1,245 \mu \mathrm{g} \mathrm{g}^{-1}$. The $\mathrm{Zn}$ contents in the other sampling sections, however, were much lower $\left(<162 \mu \mathrm{g} \mathrm{g}^{-1}\right)$. Compared with the heavy metal limits $\left(200 \mu \mathrm{g} \mathrm{g}^{-1}\right)$ adopted by the national environmental protection agencies of Slovenia and Germany, $\mathrm{Zn}$ concentrations are predominantly raised only in the soil samples from section VII (Table 1).

The presented data clearly show that the paddy soil from section VII in the vicinity of the Zletovska River is highly impacted with $\mathrm{As}, \mathrm{Cd}, \mathrm{Cu}, \mathrm{Pb}$ and $\mathrm{Zn}$. Their maximum concentration values of $47.6 \mu \mathrm{g} \mathrm{g}^{-1} \mathrm{As}$, $6.4 \mu \mathrm{g} \mathrm{g}^{-1} \mathrm{Cd}, 99 \mu \mathrm{g} \mathrm{g}^{-1} \mathrm{Cu}, 983 \mu \mathrm{g} \mathrm{g}^{-1} \mathrm{~Pb}$ and $1,245 \mu \mathrm{g} \mathrm{g}^{-1} \mathrm{Zn}$ are significantly higher than those from the other sampling sections and easily exceed the limit emission values of 20, 3, 100 and $300 \mu \mathrm{g} \mathrm{g}^{-1}$ for $\mathrm{As}, \mathrm{Cd}, \mathrm{Pb}$ and $\mathrm{Zn}$, respectively, reported by the national environmental protection agencies of Slovenia and Germany (Table 1). The analysis of heavy metals measured during this study of paddy-soil samples for their possible intersection variation showed, according to a $t$-test, statistically significant difference at $\alpha \leq 0.05$ for $\mathrm{As}, \mathrm{Cd}, \mathrm{Cu}, \mathrm{Pb}$ and $\mathrm{Zn}$ only between sampling section VII and all the other sections (I-VI) (Table 3).

In order to compare the distribution of each element in the paddy soil between the sampling sections I-VII, a box plot was employed (Fig. 3). As shown in Fig. 3, all the soil samples of the soil sections I-VI had similar median values, suggesting that their intersection differences were not substantial in most cases, while statistically significant variations existed only between sampling section VII and the other sections (I-VI).

The total concentrations of heavy metals in soils may be derived from two sources: natural and

Table 3 Results of $t$-test to evaluate the significant differences at $\alpha \leq 0.05$ between the sections I to VII for $\mathrm{As}, \mathrm{Cd}, \mathrm{Cu}, \mathrm{Pb}$ and $\mathrm{Zn}$

\begin{tabular}{|c|c|c|c|c|c|c|c|}
\hline Sections & I & II & III & IV & V & VI & VII \\
\hline I & & & & & & & $\begin{array}{c}\mathrm{As}^{*}, \mathrm{Cd}^{*}, \mathrm{Cu}^{*} \\
\mathrm{~Pb}^{*}, \mathrm{Zn}^{*}\end{array}$ \\
\hline II & & & & $\mathrm{Pb}^{*}$ & $\mathrm{Cu}^{*}$ & & $\begin{array}{c}\mathrm{As}^{*}, \mathrm{Cd}^{*}, \mathrm{Cu}^{*}, \\
\mathrm{~Pb}^{*}, \mathrm{Zn}^{*}\end{array}$ \\
\hline III & & & & & & $\mathrm{Pb}^{*}$ & $\begin{array}{c}\mathrm{As}^{*}, \mathrm{Cd}^{*}, \mathrm{Cu}^{*}, \\
\mathrm{~Pb}^{*}, \mathrm{Zn}^{*}\end{array}$ \\
\hline IV & & $\mathrm{Pb}^{*}$ & & & $\mathrm{~Pb}^{*}$ & $\mathrm{As}^{*}, \mathrm{~Pb}^{*}$ & $\begin{array}{l}\mathrm{As}^{*}, \mathrm{Cd}^{*}, \mathrm{Cu}^{*}, \\
\mathrm{~Pb}^{*}, \mathrm{Zn}^{*}\end{array}$ \\
\hline $\mathrm{V}$ & & $\mathrm{Cu}^{*}$ & & $\mathrm{~Pb}^{*}$ & & & $\begin{array}{c}\mathrm{As}^{*}, \mathrm{Cd}^{*}, \mathrm{Cu}^{*}, \\
\mathrm{~Pb}^{*}, \mathrm{Zn}^{*}\end{array}$ \\
\hline VI & & & $\mathrm{Pb}^{*}$ & $\mathrm{As}^{*}, \mathrm{~Pb}^{*}$ & & & $\begin{array}{c}\mathrm{As}^{*}, \mathrm{Cd}^{*}, \mathrm{Cu}^{*} \\
\mathrm{~Pb}^{*}, \mathrm{Zn}^{*}\end{array}$ \\
\hline VII & $\begin{array}{c}\mathrm{As}^{*}, \mathrm{Cd}^{*}, \mathrm{Cu}^{*}, \\
\mathrm{~Pb}^{*}, \mathrm{Zn}^{*}\end{array}$ & $\begin{array}{c}\mathrm{As}^{*}, \mathrm{Cd}^{*}, \mathrm{Cu}^{*} \\
\mathrm{~Pb}^{*}, \mathrm{Zn}^{*}\end{array}$ & $\begin{array}{c}\mathrm{As}^{*}, \mathrm{Cd}^{*}, \mathrm{Cu}^{*} \\
\mathrm{~Pb}^{*}, \mathrm{Zn}^{*}\end{array}$ & $\begin{array}{l}\mathrm{As}^{*}, \mathrm{Cd}^{*}, \mathrm{Cu}^{*} \\
\mathrm{~Pb}^{*}, \mathrm{Zn}^{*}\end{array}$ & $\begin{array}{c}\mathrm{As}^{*}, \mathrm{Cd}^{*}, \mathrm{Cu}^{*} \\
\mathrm{~Pb}^{*}, \mathrm{Zn}^{*}\end{array}$ & $\begin{array}{c}\mathrm{As}^{*}, \mathrm{Cd}^{*}, \mathrm{Cu}^{*}, \\
\mathrm{~Pb}^{*}, \mathrm{Zn}^{*}\end{array}$ & $\begin{array}{l}\mathrm{As}^{*}, \mathrm{Cd}^{*}, \mathrm{Cu}^{*}, \\
\mathrm{~Pb}^{*}, \mathrm{Zn}^{*}\end{array}$ \\
\hline
\end{tabular}

* Significant difference at $\alpha \leq 0.05$ 
Fig. 3 Whisker plots of As, $\mathrm{Cd}, \mathrm{Cu}, \mathrm{Pb}$ and $\mathrm{Zn}$ for soil samples from Kočani Field
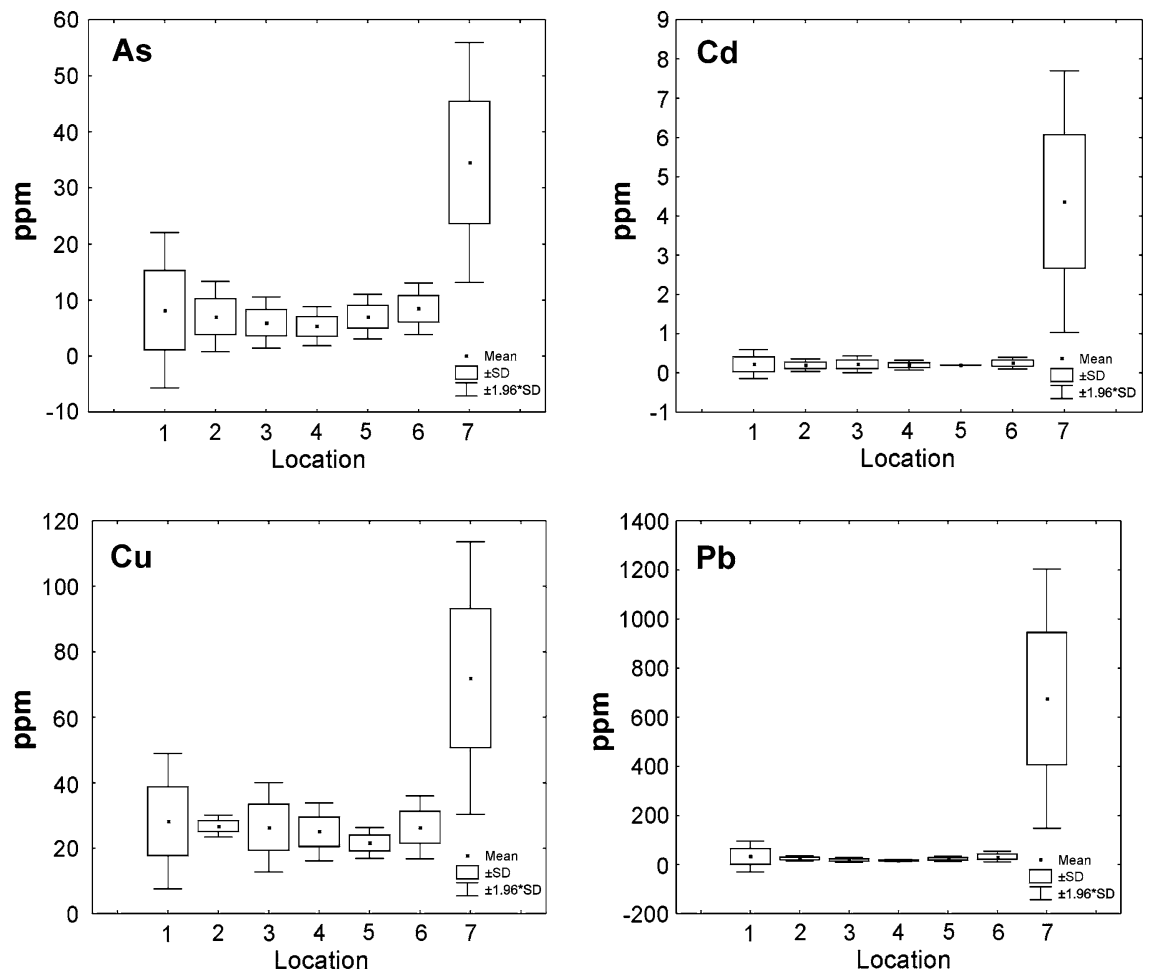

anthropogenic. Therefore, it is not easy to decide a priori which of these two contributions will represent the main source of heavy metal pollution. However, in the case of the paddy soil from section VII in the vicinity of the Zletovska River it is very clear that the anthropogenic impact due to acid mine drainage and mining activities is the main source of $\mathrm{As}, \mathrm{Cd}, \mathrm{Cu}, \mathrm{Pb}$ and $\mathrm{Zn}$ contamination. All these metals are important ore-forming elements and are paragenetically related to the $\mathrm{Pb}-\mathrm{Zn}$ polymetalic mineralization of the Zletovo-Kratovo ore district predominately drained by the Zletovska River (Dolenec et al. 2007). Many studies have revealed heavy metal contamination in soil, plant, waters and sediment from metaliferous mines and mining activities throughout the world (Adriano 1986).

Heavy metal concentrations in rice

The concentrations of $\mathrm{As}, \mathrm{Cd}, \mathrm{Cu} \mathrm{Pb}$ and $\mathrm{Zn}$ in unpolished rice grown on the paddy soils of Kočani Field together with the maximum permissible limit of 
Table 4 Total $\mathrm{As}, \mathrm{Cd}, \mathrm{Cu}, \mathrm{Pb}$ and $\mathrm{Zn}$ concentrations in unpolished rice from Kočani Field

\begin{tabular}{|c|c|c|c|c|c|c|}
\hline $\begin{array}{l}\text { Elements } \\
\text { Location }\end{array}$ & $\begin{array}{l}\mu \mathrm{g} \mathrm{g}^{-1} \\
\text { Sample }\end{array}$ & As & $\mathrm{Cd}$ & $\mathrm{Cu}$ & $\mathrm{Pb}$ & $\overline{\mathrm{Zn}}$ \\
\hline I-1 & R-1 & 0.30 & 0.010 & 3.8 & 0.1 & 31 \\
\hline I-3 & R-2 & 0.28 & 0.140 & 4.5 & 0.2 & 37 \\
\hline I-5 & R-3 & 0.22 & 0.020 & 3.8 & 0.2 & 28 \\
\hline II-1 & R-4 & 0.24 & 0.040 & 2.7 & 0.2 & 22 \\
\hline III-5 & R-5 & 0.22 & 0.010 & 2.1 & 0.1 & 21 \\
\hline III-1 & R-6 & 0.18 & 0.070 & 4.7 & 0.3 & 26 \\
\hline III-5 & R-7 & 0.19 & 0.010 & 1.2 & 0.2 & 26 \\
\hline IV-7 & R-8 & 0.42 & 0.010 & 2.0 & 0.1 & 15 \\
\hline V-1 & R-9 & 0.28 & 0.150 & 3.2 & 0.1 & 31 \\
\hline $\mathrm{V}-3$ & $\mathrm{R}-10$ & 0.33 & 0.010 & 1.3 & 0.2 & 19 \\
\hline VI-1 & $\mathrm{R}-11$ & 0.16 & 0.005 & 1.2 & 0.05 & 16 \\
\hline VI-4 & R-12 & 0.15 & 0.005 & 0.8 & 0.1 & 13 \\
\hline VII-2 & R-13 & 0.40 & 0.180 & 4.9 & 0.4 & 38 \\
\hline \multirow[t]{4}{*}{ VII-4 } & R-14 & 0.53 & 0.310 & 5.8 & 0.5 & 67 \\
\hline & 1 & & 0.1 & & 0.2 & \\
\hline & 2 & & & 10 & & \\
\hline & 3 & 0.2 & 0.15 & & 1.0 & 50 \\
\hline
\end{tabular}

Maximum permitted levels for heavy metals in food crops: (1) Commission Regulation Directive EC (2001); (2) FAO/WHO (1992) and (3) Pilc et al. (1994)

analysed heavy metal concentrations in food crops adopted by various international and national agencies are shown in Table 4. Table 5 shows the main statistical parameters (mean, median, range and standard deviation [SD]) for the analysed unpolished rice samples.

Arsenic is a metaloid and is considered as toxic to both plants and humans. It is a naturally occurring element and the levels of As in foods generally reflect normal accumulation from the environment (Roychowdhury et al. 2003). An intake of $1 \mathrm{mg}$ of inorganic As per day may give rise to skin lesions within a few years (WHO 1981). Edible plants grown on uncontaminated or unmineralized soil contain
0.01-1.5 $\mu \mathrm{g} \mathrm{g}^{-1}$ As (Kabata-Pendias and Pendias 2001). However, elevated levels of As and other heavy metals may be found in plants growing on contaminated soils. According to Lu and Zhang (2005) the As concentrations of rice from the polluted paddy soil in the Huayuan mining area (China) varied from 0.230 to $0.651 \mathrm{\mu g} \mathrm{g}^{-1}$, with a mean value of $0.437 \mu \mathrm{g} \mathrm{g}^{-1}$. Similar values in the range $0.216-$ $0.551 \mu \mathrm{g} \mathrm{g}^{-1}$ were also measured in rice from around the Chatian deposit area in China ( $\mathrm{Lu}$ and Zhang 2005).

Our previous study of the trace metal contamination of rice from ten magazines of local farmers in Kočani Field showed that the As in unpolished rice was in the range $0.11-0.52 \mu \mathrm{g} \mathrm{g}^{-1}$, with a median value of $0.18 \mu \mathrm{g} \mathrm{g}^{-1}$ (Rogan et al. 2007). The As concentrations in unpolished rice (range 0.15$0.53 \mu \mathrm{g} \mathrm{g}^{-1}$, median value $0.26 \mu \mathrm{g} \mathrm{g}^{-1}$ ) found in this study (Table 5) were slightly higher than those observed in rice from the magazines. The differences and the lower concentration levels in rice seeds from the local farmers' magazines were most probably the result of the homogenisation of rice seeds from the paddy fields with different As contents. The highest concentrations (up to $0.53 \mu \mathrm{g} \mathrm{g}^{-1}$ ) were measured in rice grown in the most impacted soils of section VII, close to the Zletovska River (Table 5). These values were, however, up to 2.7 times higher than the corresponding limit of $0.20 \mu \mathrm{g} \mathrm{g}^{-1}$ for plants used for food (Pilc et al. 1994).

$\mathrm{Cd}$ is considered as one of the most environmentally hazardous trace metals. It is easily taken up and accumulated by plants and crops through their root systems and is present in all food (Alam et al. 2003). Research undertaken over the past 40 years has identified the irrefutable relationship between longterm consumption of Cd-contaminated rice and human $\mathrm{Cd}$ diseases such as itai-itai and proximal tubular renal dysfunction (Simmons et al. 2005). The background concentrations of $\mathrm{Cd}$ in cereal grains
Table 5 Descriptive basic statistic of the elemental content in unpolished rice from Kočani Field

\begin{tabular}{llllll}
\hline Element & $\mathrm{As}\left(\mu \mathrm{g} \mathrm{g}^{-1}\right)$ & $\mathrm{Cd}\left(\mu \mathrm{g} \mathrm{g}^{-1}\right)$ & $\mathrm{Cu}\left(\mu \mathrm{g} \mathrm{g}^{-1}\right)$ & $\mathrm{Pb}\left(\mu \mathrm{g} \mathrm{g}^{-1}\right)$ & $\mathrm{Zn}\left(\mu \mathrm{g} \mathrm{g}^{-1}\right)$ \\
\hline Mean & 0.279 & 0.069 & 3.00 & 0.196 & 27.86 \\
Median & 0.26 & 0.015 & 2.95 & 0.20 & 26 \\
Minimum & 0.15 & 0.005 & 0.80 & 0.05 & 13 \\
Maximum & 0.53 & 0.310 & 5.80 & 0.50 & 67 \\
$\mathrm{SD}$ & 0.11 & 0.092 & 1.62 & 0.13 & 13.68 \\
\hline
\end{tabular}


were, in general, in the range $0.013-0.22 \mu \mathrm{g} \mathrm{g}^{-1}$ (Kabata-Pendias and Pendias 2001). The Cd content in rice grown in various countries ranged from 0.01 to $0.05 \mathrm{mg} \mathrm{g}^{-1}$ (Jung 1995). According to Yang et al. (2006) the average $\mathrm{Cd}$ concentration level in unpolished rice contaminated with untreated mining water grown in paddy fields around the $\mathrm{Pb}-\mathrm{Zn}$ mine in Lechang (southern China) was $0.24 \mu \mathrm{g} \mathrm{g}^{-1}$. An extremely high concentration of $\mathrm{Cd}\left(6.99 \mu \mathrm{g} \mathrm{g}^{-1}\right)$ was measured in rice affected by the Chenzhou $\mathrm{Pb}-\mathrm{Zn}$ mine spill in China (Liu et al. 2005).

In rice sampled during this study the $\mathrm{Cd}$ concentrations varied from 0.005 to $0.310 \mu \mathrm{g} \mathrm{g}^{-1}$, with a median value of $0.015 \mu \mathrm{g} \mathrm{g}^{-1}$ (Table 5). The measured values were similar to the background levels of $\mathrm{Cd}$ in cereal grains reported by Kabata-Pendias and Pendias (2001). However, at some sampling sites the $\mathrm{Cd}$ concentrations in unpolished rice exceed the internationally recognized maximum level (ML) for $\mathrm{Cd}$ in rice grain of $0.2 \mu \mathrm{g} \mathrm{g}^{-1}$ (CAC 2002) as well as the maximum permitted level of $0.1 \mu \mathrm{g} \mathrm{g}^{-1}$ in cereals given by the Commission Regulation Directive EC (2001) (Table 4). Similar high concentrations of $\mathrm{Cd}$ $\left(0.21 \mu \mathrm{g} \mathrm{g}^{-1}\right)$ were also determined in rice from one local magazine containing mostly the seed from paddy soils close to the Zletovska River (Rogan et al. 2007). In the study area, the highest concentrations of $\mathrm{Cd}$, like other heavy metals analysed during this study, were also measured in rice grown in the vicinity of the Zletovska River.

$\mathrm{Cu}$ is an essential element for plant growth and development. In various plants grown in uncontaminated soils $\mathrm{Cu}$ levels do not generally exceed $20 \mu \mathrm{g} \mathrm{g}^{-1}$. In cereal grains from different countries $\mathrm{Cu}$ concentrations were in the range $0.6-10.3 \mu \mathrm{g} \mathrm{g}^{-1}$. In plants grown in contaminated sites impacted by the metal-processing industry $\mathrm{Cu}$ concentrations could be as high as $560 \mu \mathrm{g} \mathrm{g}^{-1}$ (Kabata-Pendias and Pendias 2001). Jung et al. (2005) reported that the $\mathrm{Cu}$ concentrations in polished rice from South Korea were in the range of $1.29-2.53 \mu \mathrm{g} \mathrm{g}^{-1}$, with a median value of $1.85 \mu \mathrm{g} \mathrm{g}^{-1}$. Elevated $\mathrm{Cu}$ concentration levels of up to $15.5 \mu \mathrm{g} \mathrm{g}^{-1}$ were measured by $\mathrm{Cao}$ and $\mathrm{Hu}$ (2000) in brown rice grown in paddy soils irrigated with $\mathrm{Cu}$-rich wastewater. Lee et al. (2001) found that the $\mathrm{Cu}$ concentration in rice grain from heavy-metalimpacted paddy soils around the Daduk $\mathrm{Au}-\mathrm{Ag}-\mathrm{Pb}-$ $\mathrm{Zn}$ mine (Korea) range from 1.6 to $4.6 \mu \mathrm{g} \mathrm{g}^{-1}$, with a mean value of $3.1 \mu \mathrm{g} \mathrm{g}^{-1}$. According to Jung and
Thornton (1996) the average $\mathrm{Cu}$ content in most plants grown in the contaminated soil in the vicinity of the $\mathrm{Pb}-\mathrm{Zn}$ Sambo mine in Korea were, however, $<20 \mu \mathrm{g} \mathrm{g}^{-1}$.

The concentrations of $\mathrm{Cu}$ in the rice samples from the studied area varied between 0.8 and $5.8 \mu \mathrm{g} \mathrm{g}^{-1}$, with a median value of $2.95 \mu \mathrm{g} \mathrm{g}^{-1}$ (Table 5). The highest concentrations were found in rice from the most impacted sites in section VII, close to the Zletovska River (Table 4). However, in none of the 14 sampling sites did the $\mathrm{Cu}$ concentration in unpolished rice exceed the maximum permissible limit of $10 \mu \mathrm{g} \mathrm{g}^{-1} \mathrm{Cu}$ (WHO 1998). These results indicated that the $\mathrm{Cu}$ concentrations in rice from Kočani Field should not be harmful to human health through the food chain.

$\mathrm{Pb}$ is also thought to be one of the major chemically toxicologically dangerous trace metals. It is naturally present in small amounts in practically all environmental matrices. The $\mathrm{Pb}$ content in an edible portion of the plants grown in an uncontaminated area, as reported by various authors for the decade 19701980, range from 0.05 to $3 \mu \mathrm{g} \mathrm{g}^{-1}$, while the mean $\mathrm{Pb}$ content calculated for cereal grains of various countries varies from 0.01 to $2.28 \mu \mathrm{g} \mathrm{g}^{-1}$ (Kabata-Pendias and Pendias 2001). $\mathrm{Pb}$ concentrations higher than $1 \mu \mathrm{g} \mathrm{g}^{-1}$ are, however, considered to provide consumers with an excessive amount of $\mathrm{Pb}$ (Witek et al. 1992). Median concentrations for $\mathrm{Pb}$ higher than $0.190 \mu \mathrm{g} \mathrm{g}^{-1}$ were found in polished rice from South Korea (Jung et al. 2005). However, elevated concentrations of $\mathrm{Pb}$, which may present a health risk to humans, could be found in food crops growing in contaminated soil; for example, unpolished rice from the paddy soil around the $\mathrm{Pb}-\mathrm{Zn}$ Lechang mine (South China) showed mean $\mathrm{Pb}$ concentrations of about $4.67 \mu \mathrm{g} \mathrm{g}^{-1}$ (Yang et al. 2004). Similar, high $\mathrm{Pb}$ contents, which were generally in the range from 0.1 to $4.3 \mu \mathrm{g} \mathrm{g}^{-1}$, were also measured in cereal grains from the Chenzhou $\mathrm{Pb}-\mathrm{Zn}$ mine (Hunan, China) affected area (Liu et al. 2005). According to Jung and Thornton (1996) the concentrations of $\mathrm{Pb}$ in rice grain grown in soils contaminated by the $\mathrm{Pb}-\mathrm{Zn}$ mining activities in Korea averaged $0.22 \mu \mathrm{g} \mathrm{g}^{-1}$.

The range and the median concentrations of $\mathrm{Pb}$ in rice sampled during this study were found to be 0.050.5 and $0.2 \mu \mathrm{g} \mathrm{g}^{-1}$, respectively (Table 5). The highest $\mathrm{Pb}$ content (Table 4) was measured in rice collected from the most polluted sampling sites of 
section VII with the highest concentration of $\mathrm{Pb}$ and other heavy metals. The measured values indicated that $\mathrm{Pb}$ concentrations were higher than the maximum permitted levels of $0.2 \mu \mathrm{g} \mathrm{g}^{-1}$ for food crops reported by the Environmental Protection Agency of Slovenia (Table 4).

Zinc is essential for both plants and animals. However, in high concentrations it can be toxic to living organisms (Dudka et al. 1995). In edible plants from uncontaminated soils the $\mathrm{Zn}$ concentrations usually range from 1.2 to $73 \mu \mathrm{g} \mathrm{g}^{-1}$ (Kabata-Pendias and Pendias 2001). Rice sold in the USA showed slightly higher average $\mathrm{Zn}$ concentrations of about $23 \mu \mathrm{g} \mathrm{g}^{-1}$ (Nriagu and Lin 1995). Similar average values of $22.5 \mu \mathrm{g} \mathrm{g}^{-1}$ for $\mathrm{Zn}$ were also measured in rice grown in soils contaminated by $\mathrm{Pb}-\mathrm{Zn}$ mining activities in Korea (Jung and Thornton 1997). These values were much lower than those of about $43.19 \mu \mathrm{g} \mathrm{g}^{-1}$ reported for the $\mathrm{Zn}$ content in rice from the impacted area around the Chenzhou mine (Liu et al. 2005).

The $\mathrm{Zn}$ concentrations in rice measured during this study were in the range 13-67 $\mu \mathrm{g} \mathrm{g}^{-1}$, with a median value of $26 \mu \mathrm{g} \mathrm{g}^{-1}$ (Table 5), and were slightly higher relative to those (range $11.7-23.7 \mu \mathrm{g} \mathrm{g}^{-1} \mathrm{Zn}$, median $17.5 \mu \mathrm{g} \mathrm{g}^{-1} \mathrm{Zn}$ ) previously reported for unpolished rice sampled in the magazines of local farmers in Kočani Field (Rogan et al. 2007). Taking into account two limits proposed for $\mathrm{Zn}$ concentrations in crops, $50 \mu \mathrm{g} \mathrm{g}^{-1}$ in crops grown for food and $100 \mu \mathrm{g} \mathrm{g}^{-1}$ in crops grown for forage (Pilc et al. 1994), it appears that only one sample (R-4) close to the Zletovska River with $\mathrm{Zn}$ concentrations of $67 \mu \mathrm{g} \mathrm{g}^{-1}$ (Table 4) exceeded the concentration limit proposed for food crops.

The presented data suggest that unpolished rice from Kočani Field had normal concentrations of $\mathrm{Cu}$, which did not exceed the critical contents of $10 \mu \mathrm{g} \mathrm{g}^{-1}$ (WHO 1998) while those of $\mathrm{Zn}$ were found to be slightly elevated above the critical values of $50 \mu \mathrm{g} \mathrm{g}^{-1}$ for plants used as food (Pilc et al. 1994) only at sampling site VII-4, in the vicinity of the Zletovska River. Cd, however, was elevated above its limit level for food of $0.1 \mu \mathrm{g} \mathrm{g}^{-1}$ (Commission Regulation Directive EC 2001) not only in the rice sampled in section VII, but also in the rice from sampling sites I-3 (sample R-2) and V-1 (sample R9). $\mathrm{Pb}$ contents above the maximum permitted level of $0.2 \mu \mathrm{g} \mathrm{g}^{-1}$ were also measured in rice grown in the paddy soil close to the Zletovska River (Commission Regulation Directive EC 2001). The $\mathrm{Pb}$ concentrations in rice from some other sampling sites were also as high as the permitted level (Table 4). In addition, As concentration that exceeded the critical content of $0.2 \mu \mathrm{g} \mathrm{g}^{-1}$ for food (Pilc et al. 1994) by up to 2.7 times was found in the rice samples from section VII. In some other sections (I, II, IV and V) the concentrations were, however, only slightly lower. It seems that these locations are polluted with As, not only due to irrigation with polluted riverine water, but probably also from As that could be released as a result of geogenic sources.

Heavy metal accumulation in crops is a function of complex interactions between the soil, the plant and environmental factors. It has been well documented that the content of heavy metals in crop plants is closely related to the levels in the soil (Cheng et al. 2006). It is not surprising, therefore, that $\mathrm{As}, \mathrm{Cd}, \mathrm{Cu}$, $\mathrm{Pb}$ and $\mathrm{Zn}$ were the highest in the rice grown in the most impacted part of Kočani Field. It appears that the elevated concentrations of the analysed heavy metals were undoubtedly related to the past and present mining activities of the region, especially those in the Zletovo-Kratovo ore district.

Although the total heavy metal concentrations in the rice from Kočani Field can play an important role in their uptake into local diet, the potential for human intoxication by heavy metals is not simply related to the concentration in the food. The most important factor is the overall intake of a particular element during a specified period of time, usually a week (Dudka et al. 1995). The total dietary intake of heavy metals, however, is not only determined by their level in food, but also by the amount of consumed contaminated food in the whole diet and the intake of heavy metals from other sources such as drinking water, atmosphere, occupational exposure and everything in the environment (Dudka et al. 1995; Liu et al. 2005). Therefore, up to now it has been impossible to predict the human health hazard related to element toxicity based only on heavy metal concentrations in the rice sampled during this study. For a further discussion more detailed studies on the heavy metal concentration in agricultural soils, irrigation and drinking water, rice plant and other edible crops as well as a dietary study of the local population around Kočani Field are essential. 


\section{Conclusions}

In this study we examined the distribution of heavy metals ( $\mathrm{As}, \mathrm{Cd}, \mathrm{Cu}, \mathrm{Pb}$ and $\mathrm{Zn}$ ) in paddy soil and unpolished rice from Kočani Field. The results showed that the paddy soil of the western part of Kočani Field in the vicinity of the Zletovska River exhibited very elevated concentrations of $\mathrm{As}, \mathrm{Cd}, \mathrm{Cu}, \mathrm{Pb}$ and $\mathrm{Zn}$, with maximum values of 47.6, 6.4, 99, 983 and $1,245 \mu \mathrm{g} \mathrm{g}^{-1}$, which significantly exceed the limits proposed by the Slovenian and German environmental agencies.

A chemical characterization of the unpolished rice also revealed the highest concentrations of As, $\mathrm{Cd}, \mathrm{Cu}, \mathrm{Pb}$ and $\mathrm{Zn}(0.53,0.31,5.8,0.5$ and $67 \mu \mathrm{g} \mathrm{g}^{-1}$ ) for rice grown in the most polluted paddy soil in the vicinity of the Zletovska River. The concentration levels of $\mathrm{Cu}$ were below the maximum permitted value of $10 \mu \mathrm{g} \mathrm{g}^{-1}$ (WHO 1998), whereas the As and $\mathrm{Zn}$ contents exceeded their permitted values of 0.20 and $0.50 \mu \mathrm{g} \mathrm{g}^{-1}$, reported by Pilc et al. (1994) for food crops. Compared with the maximum permitted levels of $0.1 \mu \mathrm{g} \mathrm{g}^{-1}$ for $\mathrm{Cd}$ and $0.2 \mu \mathrm{g} \mathrm{g}^{-1}$ for $\mathrm{Pb}$ in cereal grains and other food crops (Commission Regulation Directive EC 2001) the $\mathrm{Cd}$ and $\mathrm{Pb}$ contents in rice grown in paddy soil close to the Zletovska River also exceeded these values. In the case of $\mathrm{As}, \mathrm{Cd}$ and $\mathrm{Pb}$, slightly elevated concentrations above the permitted values were also found in some other sampling sites of Kočani Field.

The elevated concentrations of $\mathrm{As}, \mathrm{Cd}, \mathrm{Cu}, \mathrm{Pb}$ and $\mathrm{Zn}$ in paddy soil and rice undoubtedly indicated heavy metal contamination related to mining activities and acid mine drainage-impacted riverine water, which is used by local farmers for irrigation purposes.

To predict a dietary intake of these heavy metals by the human population and to assess the possible health risk, more detailed studies on heavy metal contamination in agricultural soils, irrigation and drinking water, rice and other edible crops as well as a dietary study of the local population are needed.

Acknowledgements This research was financially supported by the Ministry of Higher Education, Science and Technology, Republic of Slovenia (Bilateral Project between Republic of Macedonia and Slovenia for the years 2004-2005), and Geoexp, d.o.o., Tržič, Slovenia. Thanks to Dr. Paul McGuiness for linguistic corrections.

\section{References}

Adriano, D. C. (Ed.). (1986). Trace elements in the terrestrial environment. New York: Springer-Verlag.

Alam, M. G. M., Snow, E. T., \& Tanaka, A. (2003). Arsenic and heavy metal contamination of vegetables grown in Samta village, Bangladesh. The Science of the Total Environment, 308, 83-96. doi:10.1016/S0048-9697(02) 00651-4.

Berrow, M. L., \& Reaves, G. A. (1984). Background levels of trace elements in soils. In Environmental Contamination (1984: London): International Conference (pp. 333-340). Edinburg: CEP Consultants.

Bowen, H. J. M. (Ed.). (1979). Environmental chemistry of the elements. New York: Academic.

CAC. (2002). Report of the 34th session of the codex committee on food additives and contaminants. The Netherlands: Rotterdam.

Cao, Z. H., \& Hu, Z. Y. (2000). Copper contamination in paddy soils irrigated with wastewater. Chemosphere, 41, 3-6. doi:10.1016/S0045-6535(99)00383-5.

Cheng, W. D., Zhang, G. P., Yao, H. G., Wu, W., \& Xu, M. (2006). Genotypic and environmental variation in cadmium, chromium, arsenic, nickel, and lead concentrations in rice grains. Journal of Zhejiang University, 7, 565-571. doi:10.1631/jzus.2006.B0565.

Commission Regulation Directive EC. (2001). Commission Regulation (EC) No. 466, Official Journal of the European Communities.

Dolenec, T., Serafimovski, T., Tasev, G., Dobnikar, M., Dolenec, M., \& Rogan, N. (2007). Major and trace elements in paddy soil contaminated by $\mathrm{Pb}-\mathrm{Zn}$ mining: $\mathrm{A}$ case study of Kočani Field, Macedonia. Environmental Geochemistry and Health, 29, 21-32. doi:10.1007/ s10653-006-9057-x.

Dudka, S., Piotrowska, M., Chlopecka, A., \& Witek, T. (1995). Trace metal contamination of soils and crop plants by the mining and smelting industry in Upper Silesia, South Poland. Journal of Geochemical Exploration, 52, 237250. doi:10.1016/0375-6742(94)00047-F.

GFME. (1992). German Federal Ministry of the Environment, Novelle zur Verordnung über das Aufringen von Klärschlamm (Bundesgesetzblatt).

Jung, M. C. (1995). Heavy metal contamination of soils, plants, waters and sediments in the vicinity of metalliferous mines in Korea. Dissertation, University of London, London.

Jung, M. C. (2001). Heavy metal contamination of soils and waters in and around the Imcheon $\mathrm{Au}-\mathrm{Ag}$ mine, Korea. Applied Geochemistry, 16, 1369-1375. doi:10.1016/ S0883-2927(01)00040-3.

Jung, M. C., \& Thornton, I. (1996). Heavy metal contamination of soils and plants in the vicinity of a lead-zinc mine, Korea. Applied Geochemistry, 11, 53-59. doi:10.1016/ 0883-2927(95)00075-5.

Jung, M. C., \& Thornton, I. (1997). Environmental contamination and seasonal variation of metals in soils, plants and waters in the paddy fields around a $\mathrm{Pb}-\mathrm{Zn}$ mine in Korea. The Science of the Total Environment, 198, 105-121. doi: 10.1016/S0048-9697(97)05434-X. 
Jung, M. C., Yun, S. T., Lee, J. S., \& Lee, J. U. (2005). Baseline study on essential and trace elements in polished rice from South Korea. Environmental Geochemistry and Health, 27, 455-464. doi:10.1007/s10653-005-4221-2.

Kabata-Pendias, A., \& Pendias, H. (2001). Trace elements in soils and plants (3rd ed.). Boca Raton: CRC.

Korre, A., Durucan, S., \& Koutroumani, A. (2002). Quantitative-spatial assessment of the risks associated with high $\mathrm{Pb}$ loads in soils around Lavrio, Greece. Applied Geochemistry, 17, 1029-1045. doi:10.1016/S0883-2927(02) 00058-6.

Lee, C. G., Chon, H. T., \& Jung, M. C. (2001). Heavy metal contamination in the vicinity of the Daduk $\mathrm{Au}-\mathrm{Ag}-\mathrm{Pb}-\mathrm{Zn}$ mine in Korea. Applied Geochemistry, 16, 1377-1386. doi:10.1016/S0883-2927(01)00038-5.

Lee, J. S., Chon, H. T., \& Kim, K. W. (2005). Human risk assessment of $\mathrm{As}, \mathrm{Cd}, \mathrm{Cu}$ and $\mathrm{Zn}$ in the abandoned metal mine site. Environmental Geochemistry and Health, 27, 185-191. doi:10.1007/s10653-005-0131-6.

Liu, H., Probst, A., \& Liao, B. (2005). Metal contamination of soils and crops affected by the Chenzhou lead/zinc mine spill (Hunan, China). The Science of the Total Environment, 339, 153-166. doi:10.1016/j.scitotenv.2004.07.030.

Lu, X., \& Zhang, X. (2005). Environmental geochemistry study of arsenic in Western Hunan mining area, P.R. China. Environmental Geochemistry and Health, V27, 313-320. doi:10.1007/s10653-004-5735-8.

Nriagu, J. O., \& Lin, T.-S. (1995). Trace metals in wild rice sold in the United States. The Science of the Total Environment, 172, 223-228. doi:10.1016/0048-9697(95) 04809-X.

Pilc, L., Rosada, J., \& Siepak, J. (1994). Heavy metals concentration in soil, water and plants in the emission region of copper foundry "Głogów". Materiaty Sesji Naukowej Instytutu Ochrony Roslin, 2, 228-232.

Rogan, N., Serafimovski, T., Jačimović, R., Dolenec, M., \& Dolenec, T. (2007). Major and trace elements in rice seeds from Kočani Field (Macedonia). Acta Chimica Slovenica, $54,623-634$.

Roychowdhury, T., Tokunaga, H., \& Ando, M. (2003). Survey of arsenic and other heavy metals in food composites and drinking water and estimation of dietary intake by the villagers from an arsenic-affected area of West Bengal, India. The Science of the Total Environment, 308, 15-35. doi:10.1016/S0048-9697(02)00612-5.

Serafimovski, T., Alderton, D. H. M., Dolenec, T., Tasev, G., \& Dolenec, M. (2005). Heavy metals in sediments and soils around the Bučim copper mine area. Geologica Macedonica, 19, 69-81.
Serafimovski, T., \& Aleksandrov, M. (Eds.). (1995). Lead and zinc deposits and occurrences in the Republic of Macedonia. Special edition of RGF, No. 4, 387 pp., with extended summary in English, Stip.

Simmons, R. W., Pongsakul, P., Saiyasitpanich, D., \& Klinphoklap, S. (2005). Elevated levels of cadmium and zinc in paddy soils and elevated levels of cadmium in rice grain downstream of a zinc mineralized area in Thailand: Implications for public health. Environmental Geochemistry and Health, 27, 501-511. doi:10.1007/s10653-0057857-z.

Uradni list RS. (1996). Uredba o mejnih opozorilnih in kritičnih emisijskih vrednostih nevarnih snovi v tleh. Uradni list, 68, 5773-5774.

Whitby, L. M., Gaynor, J., \& Maclean, A. J. (1978). Metals in soils of some agricultural watersheds in Ontario. Canadian Journal of Soil Science, 58, 325-330.

WHO. (1981). Task group on environmental health criteria for arsenic: Arsenic. Environmental Health Criteria, pp. 1174. (Geneva, Switzerland).

WHO. (1992). Cadmium (EHC no. 134). Geneva, Switzerland. WHO. (1998). Copper (EHC no. 200). Geneva, Switzerland.

Witek, T., Piotrowska, M., \& Motowicka-Terelak, T. (1992). Scope and methods of changing the structure of the agriculture in the most contaminated areas of Katowice district I. Tarnowskie Gory region. Technical report (Pulawy).

Witte, K. M., Wanty, R. B., \& Ridley, W. I. (2004). Engelman spruce (Picea engelmannii) as abiological monitor of changes in soil metal loading related to past mining activity. Applied Geochemistry, 19, 1367-1376. doi: 10.1016/j.apgeochem.2004.01.022.

Wong, S. C., Li, X. D., Zhang, G., Qi, S. H., \& Min, Y. S. (2002). Heavy metals in agricultural soils of the Pearl River Delta, South China. Environmental Pollution, 119, 33-44. doi:10.1016/S0269-7491(01)00325-6.

Yang, Q. W., Lan, C. Y., Wang, H. B., Zhuang, P., \& Shu, W. S. (2006). Cadmium in soil-rice system and health risk associated with the use of untreated mining wastewater for irrigation in Lechang, China. Agricultural Water Management, 84, 147-152. doi:10.1016/j.agwat.2006. 01.005 .

Yang, Q. W., Shu, W. S., Qiu, J. W., Wang, H. B., \& Lan, C. Y. (2004). Lead in paddy soils and rice plants and its potential health risk around Lechang Lead/Zinc Mine, Guangdong, China. Environment International, 30, 883889. doi:10.1016/j.envint.2004.02.002. 